\title{
Morphometric and alloenzymatic characterisation in the Albanian honeybee population Apis mellifera $L$
}

\author{
S Dedej ${ }^{1}$, A Biasiolo ${ }^{2}$, R Piva ${ }^{2}$ \\ 1 Department of Animal Production, Agricultural University of Tirana, Albania; \\ 2 Department of Applied Biology for Defence of Plants, Udine University, Italy
}

(Received 3 March 1995; accepted 1 February 1996)

\begin{abstract}
Summary - With the aim of determining their taxonomic status, honeybee populations from Albania were compared with Apis mellifera carnica, $A$ m macedonica and $A$ m ligustica populations from Croatia, Greece and Italy, respectively. Using an electrophoretic analysis of four enzyme systems and discriminant analysis of 15 morphometric characters of the right forewing, we found that Albania represents an area of hybridisation between the subspecies $A$ m carnica and $A$ m macedonica. Albanian territory should be considered the southern border of the distribution of $A$ m carnica.
\end{abstract}

honeybee / Apis mellifera carnica / Apis mellifera macedonica / Apis mellifera ligustica / Albania / honeybee population / morphometric characterisation / alloenzymatic characterisation

\section{INTRODUCTION}

In Albanian territory, three races of honeybees are in contact: Apis mellifera carnica in the north and east (Vlatkovic and Kulincevic, 1958; Ruttner, 1988); $A$ m macedonica in the south-east; and $A m$ cecropia in the south (Infantidis, 1979). Nuri identified honeybees in Albania as A m carnica Pollman (Nuri, 1963). Before the World War II some honeybee colonies from the Italian race $A m$ ligustica were brought into Albania (Nuri, 1972). For 50 years after World War II no selling or buying took place between Albanian beekeepers and those in surrounding countries. It is important to specify that $\mathbf{5 0}$ years ago most honeybee families were in primitive hives and only a few were in modern hives.

Based on the studies made by Infantidis et al (Infantidis, 1979; Badino et al, 1988b), the Albanian honeybee is in a transition zone and may be a hybrid between different races as a result of contact in this region. For discrimination from closely related races in the Balkans, a very detailed analysis is needed (Ruttner, 1978). From this point of view, the status of the Albanian honeybee may not yet be considered as definitive.

The loci that control gene-enzyme systems can be used as a diagnostic instrument (Badino et al, 1988a). Enzymes like 
malate dehydrogenase- 1 ( $m d h-1)$, malic enzyme ( $m e$ ) and esterase-3 (est-3) (Badino et al, 1983; Badino et al, 1985; Sheppard and McPheron, 1986; Badino et al, 1988a; Biasiolo and Nazzi, 1991) were extensively used in studies of population of European races of $A$ mellifera. Aldehyde oxidase provides additional characterisation of some honeybee races (Biasiolo and Comparini, 1991) and can be useful for studying patterns of hybridisation (Biasiolo and Nazzi, 1991). Morphometric characters taken from the forewing can also be used to determine subspecific affinities (Ruttner, 1988).

The aim of the present research was to more fully characterize Albanian honeybees, using both morphometric and biochemical analyses.

\section{MATERIALS AND METHODS}

Samples consisting of adult worker honeybees (five per hive) were collected from 14 apiaries belonging to various races located in Bologna, Italy (the distribution area of $A m$ ligustica), Zagreb, Croatia (A $m$ carnica), Thessaloniki, Greece (A $m$ macedonica) and Albania (Burrel, Kavaja, Kruja, Kukës, Pogradec, Saranda, Tepelena, Tirana, fig 1).

Each apiary had between 10 and 50 hives, and bees were collected at random from ten hives during the months of April and May 1993. Most of the apiaries were stationary and neither queen importation nor movement had recently occurred. Bees were captured at the entrance or occasionally inside the hive.

The samples were transported live from Greece, Croatia and Bologna to Udine Univer-

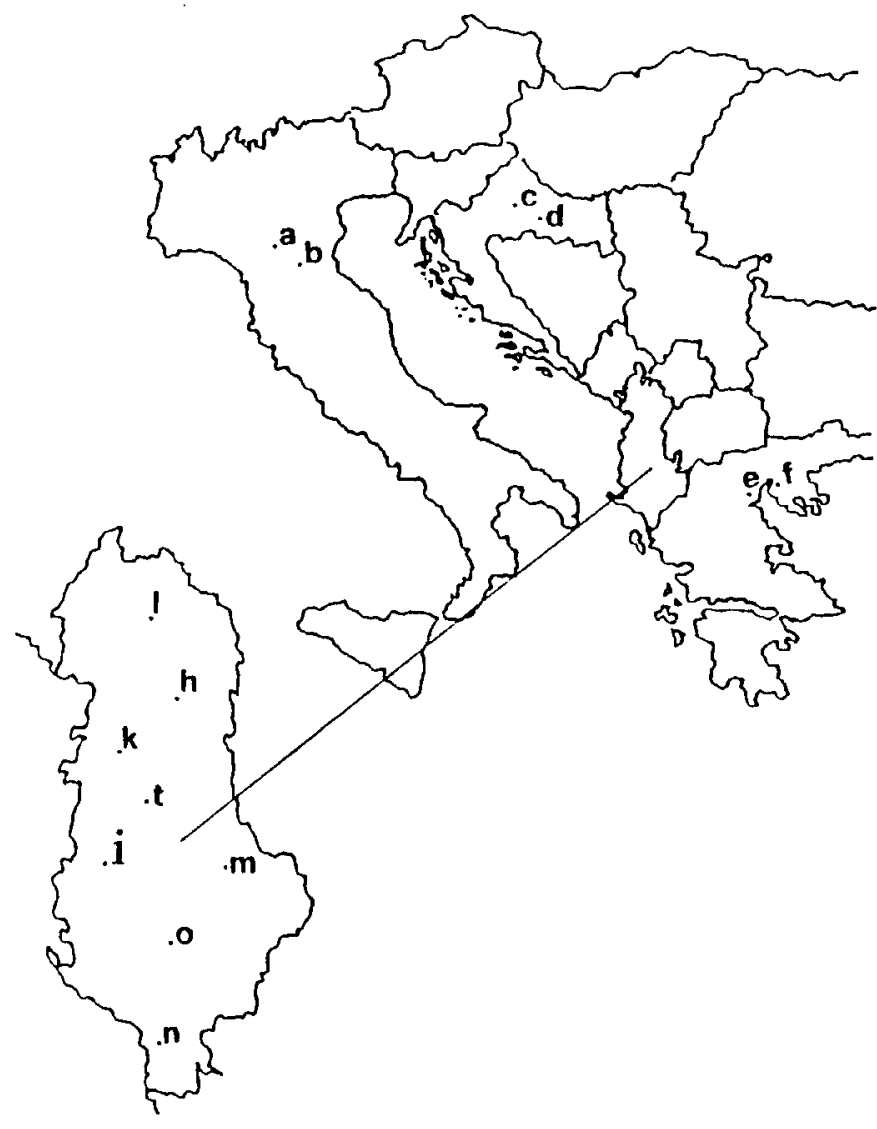

Fig 1. Sites of origin of the bee samples analysed: $A$ $m$ ligustica: a Bologna-1, b Bologna-2; $A$ m carnica: c Zagreb-1, d Zagreb-2; $A$ $m$ macedonica: e Thessaloniki-1, $f$ Thessaloniki-2; Albanian samples: $\mathbf{h}$ Burreli, i Kavaja, k Kruja, I Kukës, m Pogradec, $\mathbf{n}$ Saranda, o Tepelena, $\mathbf{t}$ Tirana. 
sity, whereas the Albanian samples were frozen and transported as soon as possible to the laboratory. All the samples were stored at $-40^{\circ} \mathrm{C}$ until needed.

The right forewing was cut off at the base and mounted on slides using a drop of Hoyerís liquid and allowed to dry. The following 15 characters of the right forewing of 20 bees per hive were measured (Ruttner, 1988; Nazzi, 1992a; Dedej and Nazzi, 1994): 1) cubital vein, distance $a ; 2$ ) cubital vein, distance $b$; 3) distance $c$; 4) distance $d$; 5) angle $A_{4} ; 6$ ) angle $B_{4} ; 7$ ) angle $D_{7} ; 8$ ) angle $E_{9} ; 9$ ) angle $G_{18} ; 10$ ) angle $J_{10} ; 11$ ) angle $J_{16} ; 12$ ) angle $K_{19} ; 13$ ) angle $L_{13} ; 14$ ) angle $N_{23} ; 15$ ) angle $O_{26}$. (fig 2)

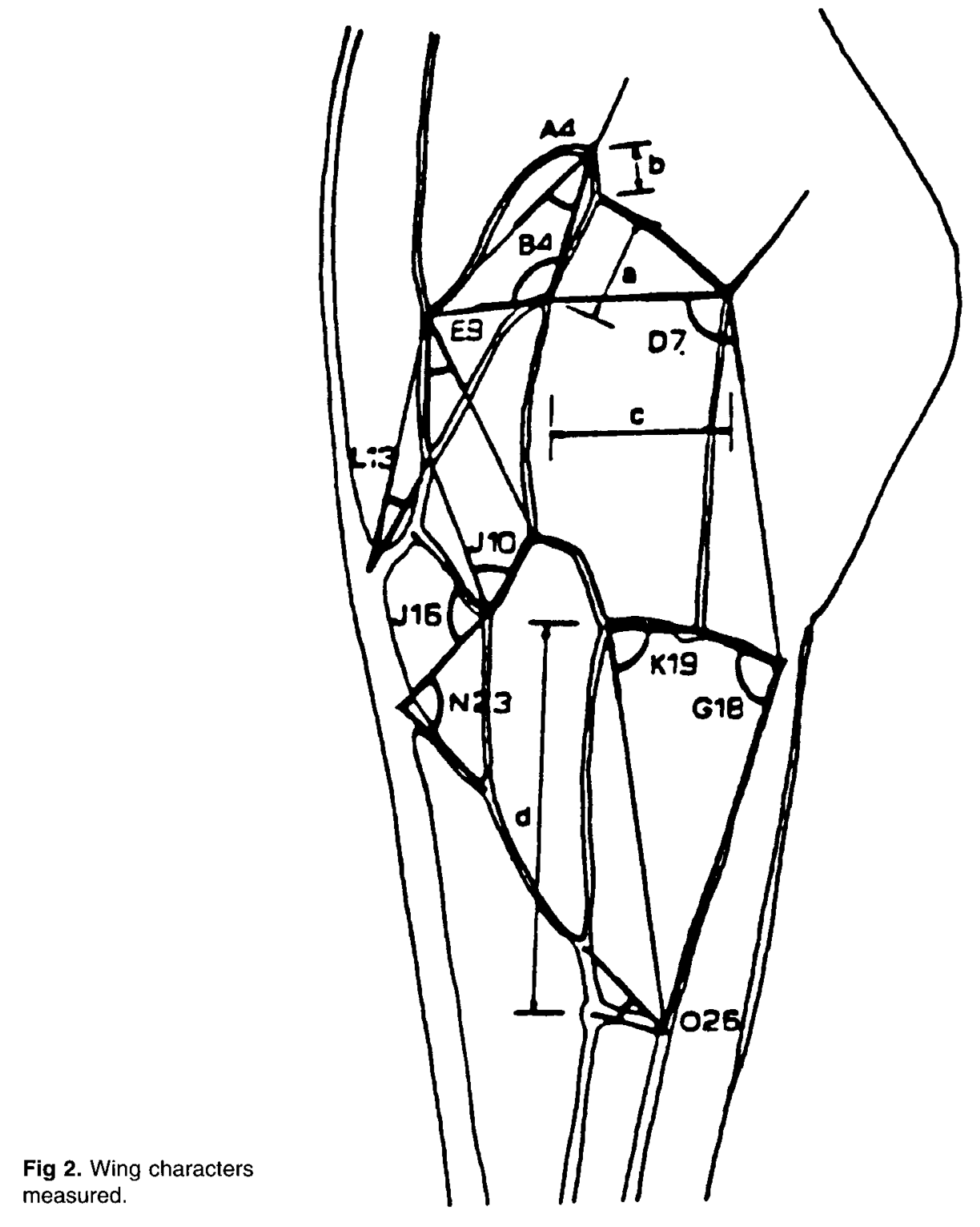


The distances and angles were measured with the computer-based system, Acquired Data and Elaboration System, produced by On-LINE SRL of Parma (Italy) and provided by the National Institute of Apiculture of Bologna (Italy).

The distances $c$ and demployed in fluctuating asymmetry and honeybee taxonomy ( $\mathrm{Nazzi}$, 1992b) were used instead of length and width of forewing as good estimates of forewing length and width (Dedej and Nazzi, 1994).

The heads and thoraces of the bees were electrophoretically analysed. Tris-citrate buffer with a $\mathrm{pH}$ value of 7.5 was used for horizontal electrophoresis on starch gels, following standard techniques (Harris and Hopkinson, 1976; Richardson et al, 1986; Biasiolo and Comparini, 1991). The enzymes and respective loci analysed were as follows: malate dehydrogenase- 1 $(m d h-1)$, malic enzyme (me), esterase-3 (est-3) and aldehyde oxidase (ao).

\section{Statistical analysis}

The mean and standard deviation of the morphometric characters measured were calculated for each apiary. Differences among samples for various characters measured were calculated using analysis of variance (Fisher test) ANOVA (Wilkinson et al, 1992). Relationships among various samples were established through a multivariate discriminant analysis, calculating the ellipses of equal concentration ( $P=0.05$; Langonegro and Feoli, 1985), which were used to measure the relative position precisely of samples coming from four areas (fig 3 ). For these purposes, the SYNTAX program (Podani, 1990a, b) was used.

For the alloenzymatic characterisation based on allele frequencies, genetic distances were calculated and the UPGMA method was used to construct a dendogram (fig 4), of relationships among the populations. Data were analysed with BIOSYS (Swofford and Selander, 1981).

\section{RESULTS AND DISCUSSION}

The results of univariate analysis for morphometric data are reported in table I. Taking into consideration all samples studied, a significant difference was found among them for 12 characters $(P<0.05)$.

Albanian samples were statistically different from those of three other races for the following characters: distances $a$ and $c$, cubital index, and angles $A_{4}, B_{4}, D_{7}, J_{16}$ and $K_{19}$ were compared with $A$ m ligustica; distance $d$ and angles $J_{10}, L_{13}, N_{23}$ and $K_{19}$ were compared with $A$ m carnica; distance $d$ and angles $A_{4}, B_{4}, E_{9}, J_{10}$ and $G_{18}$ were compared with $A$ m macedonica.

The samples of $A m$ ligustica and A $m$ carnica were statistically different for the characters distances $a, c$ and $d$, and angles $B_{4}, L_{13}$ and $J_{16}$; whereas those of $A$ m ligustica and $A m$ macedonica differed in distances $b$ and $d$, cubital index, and angles $D_{7}, G_{18}, J_{16}$ and $K_{19}$. Those of $A m$ carnica and $A m$ macedonica were different for angles $D_{7}, E_{9}, G_{18}, L_{13}$ and $N_{23}$.

The ellipse of equal concentration including all Albanian samples partly covered the ellipses of the $A$ m carnica and $A m$ macedonica populations, but did not come in contact with the ellipse of A m ligustica (fig 3 ). In the framework of the Albanian population, those coming from the north-east impinged mostly on a discriminate plane of the $A m$ carnica ellipse, while those coming from central and south Albania were dispersed inside of the three ellipses of equal concentration of A m carnica, A m macedonica and the Albanian samples. From this point of view, the Albanian population represents a hybridisation between $A m$ carnica and $A$ $m$ macedonica and Albanian territory should be considered the southern border of distribution of $A$ m carnica race.

We did not measure samples from $A$ m cecropia, the northern limit of which is near the southern border. However, based on reported morphometric characteristics of this race, including cubital index and length of proboscis (Ruttner, 1988), compared to our Albanian samples and those of Nuri (1972) and considering that a chain of mountains divides the southern Albania from 


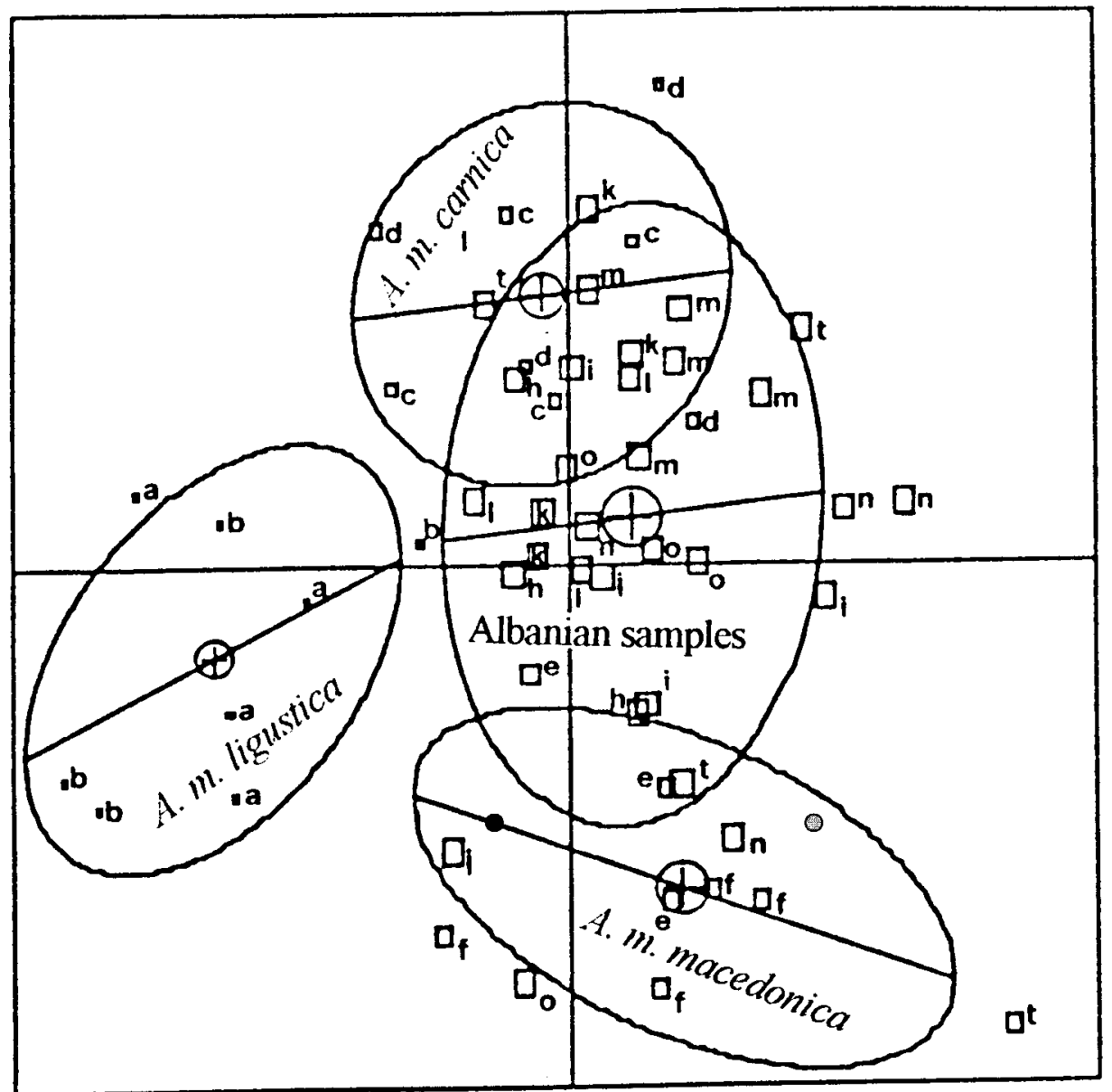

Fig 3. Discriminant analysis of morphometric characters of the 56 hives considered. A $m$ ligustica: a Bologna-1, b Bologna-2; A m carnica: c Zagreb-1, d Zagreb-2; $A$ m macedonica: e Thessaloniki-1, f Thessaloniki-2. Albanian samples: h Burreli, i Kavaja, k Kruja, I Kukës, $\mathbf{m}$ Pogradec, $\mathbf{n}$ Saranda, o Tepelena, t Tirana.

northern Greece, we think that Albanian populations may be excluded from any relationship with this race.

Allele frequencies of four loci are reported in table II.

\section{Est-3}

In the Albanian honeybee samples analysed, three alleles were observed; est-3F,
est-3M, and est-3S. Based on their relative mobility, these alleles correspond to est$3^{130}$, est $-3^{100}$ and est $-3^{70}$ (Sheppard and McPheron, 1986). The allele est-3M was observed in all samples analysed, and was fixed in two samples of $A m$ macedonica. The frequency of est-3F in the Albanian honeybee populations is similar to the frequency est-3F found by other authors (Badino et al, 1988a,b; Biasiolo and Comparini, 1991) in A m carnica and A $m$ ligus- 

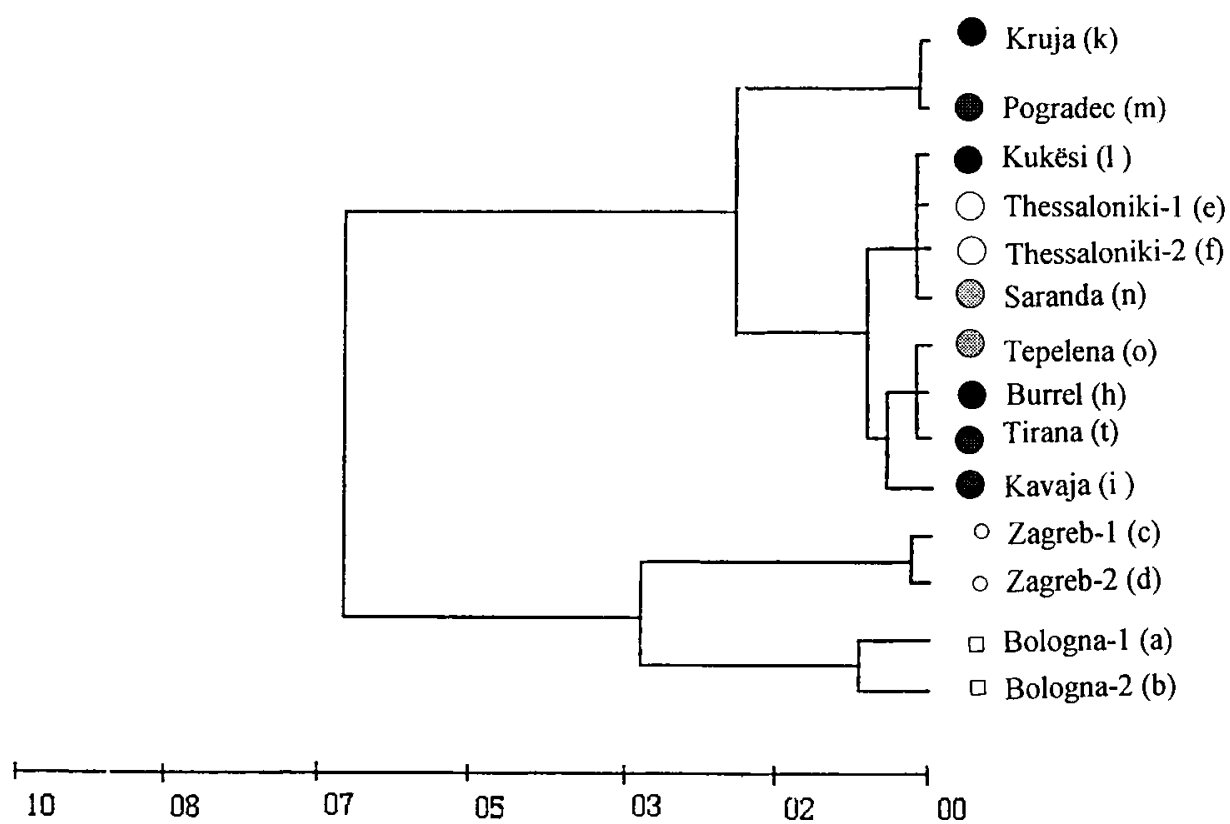

Fig 4. Dendogram obtained from the matrix of the genetic distances. o A m carnica; $O A$ m macedonica; [- A m ligustica; north Albanian samples; central Albanian samples; south Albanian samples.

tica. Only in two Albanian honeybee samples was the est-3S allele observed, which is more common in A $m$ sicula (Comparini and Biasiolo, 1991).

\section{Mdh-1}

Two alleles of this locus, $m d h-1 F$ and $m d h$ $1 S$, which on the basis of their relative mobility correspond, respectively, to $m d h-1100$ and $m d h-165$ (Sheppard and Berlocher, 1985), were observed in all the samples studied. The allelic frequency observed was comparable to previous works (Badino et al, 1988a, b; Biasiolo and Comparini, 1991). Average values of $m d h-1 F$ varied from 0.28 in $A$ m camica samples, 0.34 in those of $A m$ ligustica, 0.69 (0.55-0.91) in Albanian honeybee samples, to 0.71 in $A m$ macedonica samples.

\section{Me}

This locus generally showed a low variability, excluding the sample collected in Kavaja. This enzymatic system does not supply any remarkable contribution to the characterisation of races considered.

Ao

All the samples of $A$ m ligustica showed a higher variability, whereas among the others, only one Albanian sample was not monomorphic.

\section{CONCLUSIONS}

Cluster analyses applied from obtained data, for four variable enzymatic systems, allowed 


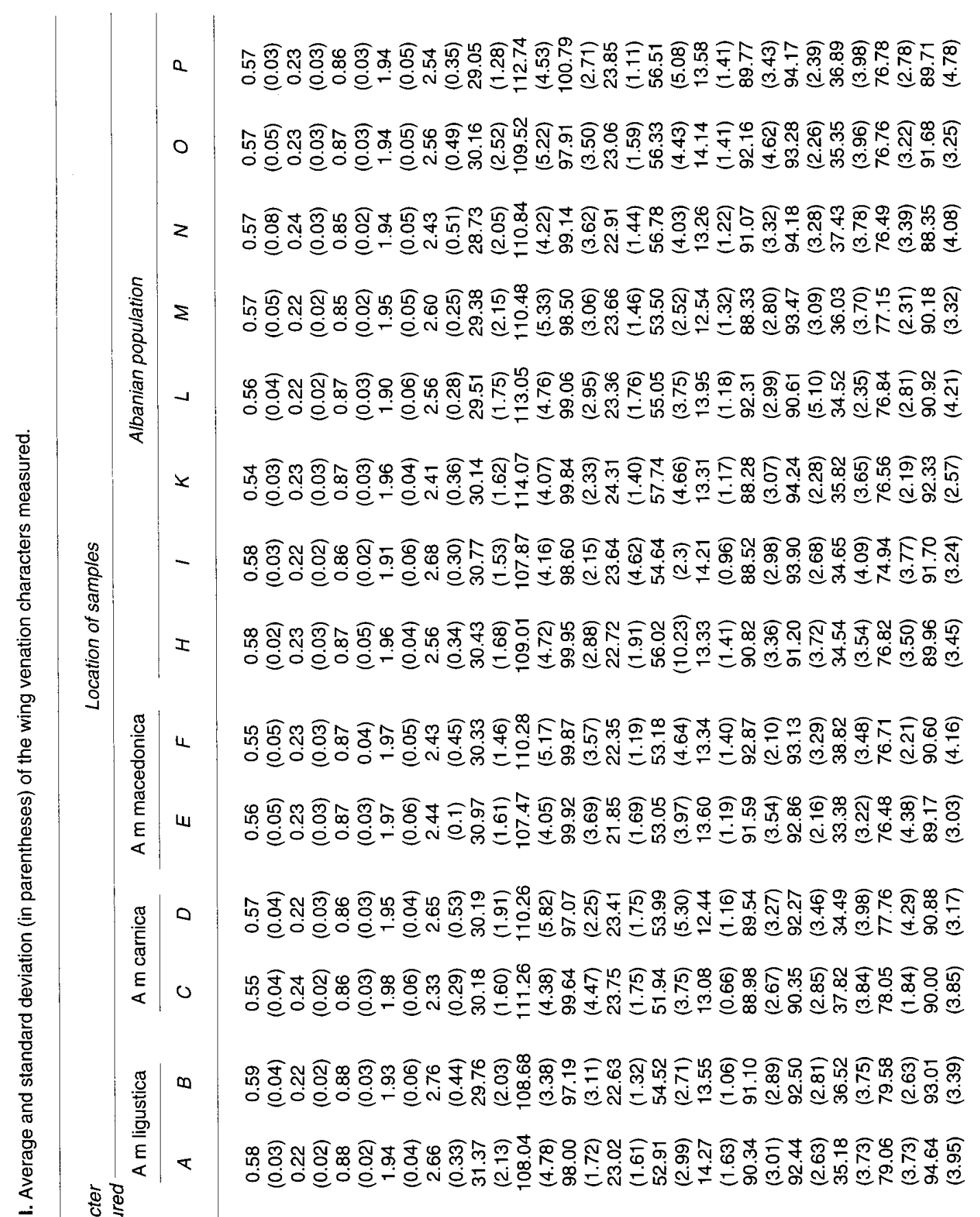
○ं

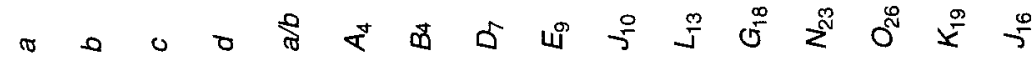




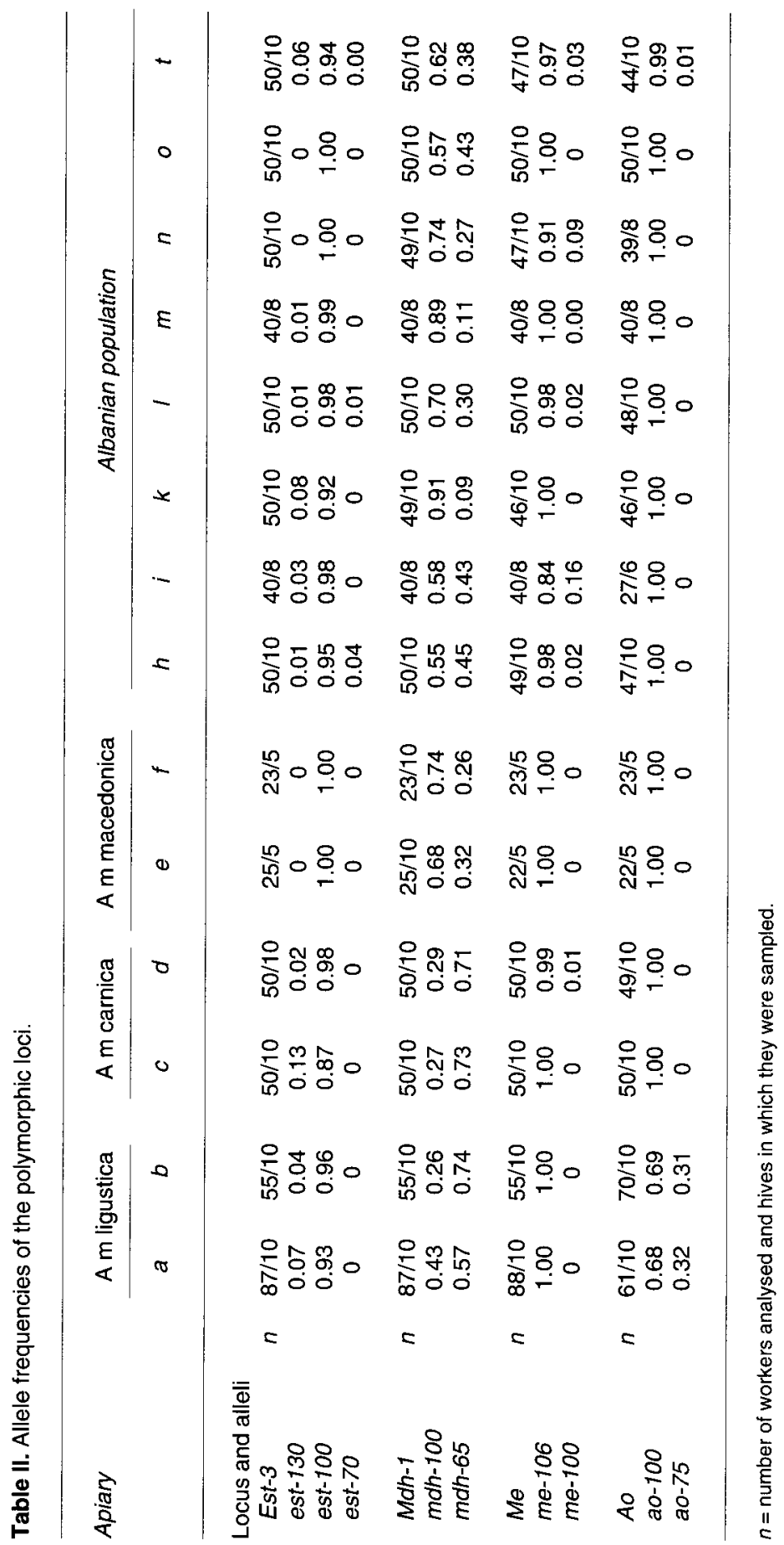


us to separate analysed samples into three groups: i) the group relative to the subspecies $A$ m ligustica; ii) the group relative to the subspecies $A m$ carnica; and iii) the group comprised of both the Albanian honeybee and $A$ m macedonica samples.

These data leave us with a close hypothetical relationship between the population of honeybees in Albania and the honeybees belonging to the subspecies $A m$ macedonica, whereas based on morphometric data in our study, the honeybees in Albania presents a hybrid between $A$ m carnica and $A m$ macedonica.

Taking into consideration both the morphometric and alloenzymatic data, the following may be concluded. The population of honeybees in Albania is either in a transition zone or a zone of prior contact among three races, and therefore seems to more closely resemble honeybees of the subspecies $A m$ macedonica than those of A m carnica, but they cannot be considered to be $A$ m macedonica or A m carnica. Albanian territory should be considered as the southern border of distribution of $A \mathrm{~m}$ carnica race.

\section{ACKNOWLEDGMENTS}

The authors wish to thank the D Sulimanoviç (Zagabria), M Ifantidis (Thessaloniki), M Lodesani and $E$ Carpana (Bologna) for supplying the samples; Istituto Nazionale di Apicoltura (Bologna e Reggio Emilia) for its hospitality and for consenting the measuring equipment; D Wagner and H Meinzer (American SARA project for Albania) for English correction. A special thanks to F Frilli and F Nazzi (University of Udine) for critical revision of the text. This work was supported financially by the law 19/1 - 1991 of the Italian Government.

\section{Résumé - Caractérisation morphomé- trique et allozymique de la population d'abeilles Apis mellifera L d'Albanie. Afin}

de déterminer leur statut taxonomique, les populations d'abeilles d'Albanie ont été comparées à des populations d'Apis mellifera carnica, $A$ m macedonica et $A m$ ligustica provenant respectivement de Croatie, de Grèce et d'Italie. Les échantillons, constitués d'abeilles ouvrières adultes (cinq par ruche), ont été prélevés dans 14 ruchers de diverses races répartis à Bologne, Italie (aire de répartition d' $A m$ ligustica), à Zagreb, Croatie ( $A$ m carnica), à Thessalonique ( $A m$ macedonica) et en Albanie (fig 1). Le locus qui contrôle les systèmes gènes-enzymes, ainsi que certains caractères de l'aile antérieure droite, ont été utilisés comme outil de diagnostic. Quinze caractères morphologiques de l'aile antérieure droite (distances a-d ; angles A4, B4, D7, $E_{9}, G_{18}, J_{10}, J_{16}, K_{19}, L_{13}, N_{23}$ et $O_{26}$ : fig 2) ont été mesurés et utilisés pour l'analyse discriminante des données. Les distances et les angles ont été mesurés avec le système informatique Acquired Data Elaboration System, produit par On-Line SRL à Parme (Italie) et fournit par l'Institut national d'apiculture de Bologne. Les têtes et les thorax d'abeilles ont été analysés par électrophorèse selon les méthodes standard. Les enzymes et leur locus respectif analysés sont les suivants : malate déshydrogénase$1(m d h-1)$, acide malique $(m e)$, estérase-3 (est-3) et aldéhyde oxydase (ao). Par une analyse discriminante multivariée on a calculé les ellipses d'égale concentration ( $p=$ 0,05 ; Langonegro et Feoli, 1985). Elles ont été utilisées pour mesurer précisément la position relative des échantillons provenant des quatre régions. La figure 3 montre que l'ellipse d'égale concentration englobant tous les échantillons d'Albanie recouvre partiellement celle d'A $m$ carnica et celle d' $A$ $m$ macedonica, mais n'est pas en contact avec celle d'A $m$ ligustica. Pour la caractérisation allozymique, basée sur la fréquence des allèles, on a calculé les distances génétiques et la méthode UPGMA a été utilisée pour construire un dendogramme des relations parmi les populations considérées (fig 
4). L'analyse de groupe appliquée aux données obtenues pour les quatre systèmes enzymatiques variables a montré une relation possible étroite entre la population d'abeilles d'Albanie et les abeilles appartenant à la sous-espèce $A m$ macedonica alors que, d'après les données morphologiques de notre étude, les abeilles d'Albanie se présentent comme des hybrides d' $A m$ carnica et d'A $m$ macedonica. Si l'on prend en compte à la fois les données morphologiques et allozymiques, on peut conclure que la population d'abeilles d'Albanie, étant située soit à une zone de transition, soit à une zone de contact antérieur entre les trois races, semble plus proche d'A $m$ macedonica que d'A m carnica, mais qu'elle ne peut pas être considérée comme appartenant ni à $A m$ macedonica, ni à $A m$ carnica. Le territoire albanais doit être considéré comme la bordure méridionale de l'aire de répartition de la race $A$ m carnica.

\section{Apis mellifera / génétique population / morphométrie / allozyme / Albanie}

\section{Zusammenfassung - Morphometrische und alloenzymatische Charakterisierung} der albanischen Honigbienenpopulation (A mellifera $L$ ). Albanische Populationen der Honigbiene wurden mit dem Ziel einer taxonomischen Einordnung mit $A$ m carnica aus Kroatien, $A$ m macedonica aus Griechenland und $A$ m ligustica aus Italien verglichen. Die Proben verschiedener Rassen entstammten 14 Bienenständen in Bologna/ Italien (Verbreitungsgebiet von $A$ m ligustica), Kroatien ( $A$ m carnica), Thessaloniki, Griechenland (A $m$ macedonica) und Albanien (Abb 1); pro Volk wurden 5 Arbeiterinnen entnommen. Zur Diagnose wurden die für alloenzymatischen Gensysteme verantwortlichen Loci sowie einige Kenngrößen des rechten Vorderflügels herangezogen. Es wurden fünfzehn morphometrische Kennzeichen des rechten Vorderflügels vermessen (Abb 2): die Strecken Cubitalader a,
Cubitalader b, die Entfernungen $\mathrm{c}$ und $\mathrm{d}$; die Winkel A4, B4, D7, E9, G18, J10, J16, $\mathrm{K} 19, \mathrm{~L} 13, \mathrm{~N} 23$ und O26. Zur Vermessung der Entfernungen und Winkel wurde das rechnergestützte Erfassungssystem "Acquired Data and Elaboration System" der Fa. On-LINE S.R.L in Parma vom National Institute of Apiculture in Bologna (Italien) verwendet. Die Messungen wurden in Diskriminanzanalysen ausgewertet. Kopf und Thorax der Bienen wurden elektrophoretisch nach Standardprozeduren untersucht. Die untersuchten Enzyme bzw die entsprechenden genetischen Loci waren: Malatdehydrogenase-1 (Mdh-1), Malat-Enzym ( $m e$ ), Esterase-3 (est-3) und Aldehydoxidase (ao). Über multivariate Diskriminanzanalysen wurden Ellipsen gleicher Konzentration berechnet $(P=0.05$; Langonegro und Feoli, 1985), aus diesen ist die genaue Position der Proben aus den vier Untersuchungsgebieten ersichtlich. Es zeigte sich, daß die Ellipse der albanischen Proben sich teilweise mit den Ellipsen der Populationen von A $m$ carnica und $A m$ macedonica überschnitten, aber keinerlei Kontakt mit der Ellipse von $A$ $m$ ligustica hatte (Abb 3). Aus der alloenzymatischen Charakterisierung auf Grundlage der Genfrequenzen wurden genetische Entfernungen kalkuliert und auf Basis der UPGMA-Methode ein Dendrogramm der Beziehungen zwischen den betrachteten Populationen erstellt (Abb 4). Eine Clusteranalyse der aus vier variablen enzymatischen Systemen erhaltenen Daten ergaben eine nahe hypothetische Beziehung zwischen der Bienenpopulation in Albanien und den Bienen der Unterart $A$ m macedonica, während diese nach den morphometrischen Daten Hybriden zwischen A $m$ carnica und A $m$ macedonica darstellen. Bei Berücksichtigung sowohl der morphometrischen als auch der alloenzymatischen Ergebnisse kann festgestellt werden, daß die Honigbienenpopulation von Albanien in einem Bereich des Überganges oder frühen Kontaktes zwischen drei Rassen eher der Unterart $A$ m macedonica als $A$ m carnica ähneln; 
dennoch können sie weder als $A$ m macedonica noch als $A$ carnica bezeichnet werden. Das albanische Gebiet sollte daher als südliche Grenze der Verbreitung von $A$ $m$ carnica betrachtet werden.

\section{Apis mellifera carnica / Apis mellifera macedonica / Apis mellifera ligustica / Albanien / Honigbienenpopulation / Mor- phometrie / Alloenzymatische Charakte- risierung}

\section{REFERENCES}

Badino G, Celebrano G, Manino A (1983) Population structure and Mdh-1 locus variation in Apis mellifera ligustica. J Hered 74, 443-446

Badino G, Celebrano G, Manino A, Longo S (1985) Enzyme polymorphism in the Sicilian honeybee. Experientia 41, 752-754

Badino G, Celebrano G, Manino A (1988a) Genetica di popolazione delle sottospecie mediterranee di Apis mellifera $\mathrm{L}$ sulla base di varianti alloenzimatiche. Apic Mod 79, 233-239

Badino G, Celebrano G, Manino A, Ifantidis D (1988b) Allozyme varibility in Greek honeybees (Apis mellifera L). Apidologie 19, 377-386

Biasiolo A, Comparini A (1991) Genetics of aldehyde oxidase, a new polymorphic locus in Apis mellifera. $J$ Genet Breed 45, 103-106

Biasiolo A, Nazzi F (1991) Analisi elettroforetica e morfometrica di campioni di Apis mellifera provenienti da una zona di ibridazione razziale. Atti Convegno Murst 'Stato attuale e Svilupo della ricercha in apicoltura', Sassari, 47-58

Comparini A, Biasiolo A (1991) Genetic descrimination of Italian Bee, Apis mellifera ligustica versus Carnolian bee, Apis mellifera carnica by allozyme variability analysis. Biochem Syst Ecol 19, 189-194

Dedej S, Nazzi F (1994) Two distances of the fore-wing venation as estimates of wing size. J Apic Res 33 , $59-61$
Harris H, Hopkinson D.A (1976) Handbook of Enzyme Electrophoresis in Human Genetics. North Holland Publ, Amsterdam

Ifantidis M (1979) Morphological characters of the Greek bee Apis mellifera cecropia. XXVII Int Congr Apic, Athens. Apimondia, Bucarest, 257-263

Langonegro M, Feoli $E$ (1985) The use of ellipses of equal concentration to analyse ordination vegetation patterns. Stud Geobot 5, 143-165

Nazzi F (1992a) Morphometrical analysis of honeybees from an area of racial hybridization in northeastern Italy. Apidologie 23, 89-96

Nazzi F (1992b) Fluctuation of forewing characters in hybrid honey bees from north-eastern Italy. J Apic Res 31, 27-31

Nuri $Q$ (1963) Veçoritè morfologjike te bletès sè vendit. Bul Shk Bujqèsore 2, 126-150 [in Albanian]

Nuri Q (1972) Rritja e bletès. Botim i LB-sè -Tiranè, 308 $\mathrm{p}$ [in Albanian]

Podani J (1990a) SYN.TAX IV. Computer programs for data analysis in ecology and systematics on IBM$P C$ and Macintosh computers. CETA, Gorizia, $145 p$

Podani $J(1990 b)$ Supplementary programs to SYNTAX IV. CETA, Gorizia, $93 \mathrm{p}$

Richardson BJ, Baverstock PR, Adams M (1986) Allozyme Electrophoresis. A Handbook for Animal Systematic and Population Studies. Academic Press, Australia, $410 \mathrm{p}$

Ruttner F, Tassencourt L, Louveveaux (1978) Biometrical-statistical analysis of the geographic variability of Apis mellifera L. Apidologie 9, 363-381

Ruttner F (1988) Biogeography and Taxonomy of Honeybees. Springer-Verlag, Berlin, $284 \mathrm{p}$

Sheppard WS, Berlocher SH (1985) New allozyme variability in Italian honey bees. $J$ Hered 76, 45-48

Sheppard WS, McPheron BA (1986) Genetic variation in honey bees from an area of racial hybridization in western Czechoslovakia. Apidologie 17, 21-32

Swofford DL, Selander RB (1981) Biosys-1. J Hered 72 , 281-283

Vlatkovic B, Kulincevic J (1958) Beitrag zu morphologischen an Bienen in Sudserbien. XVII Int Congr Apic, Roma, 251-252

Wilkinson L, Hill M, Vang E (1992) SYSTAT for the Macintosh, Version 5.2. Evanston, $724 p$ 